\title{
Impact of Micro-Finance on Business Creation: A Case of Nepal
}

\author{
Bharat Ram Dhungana, $\mathrm{PhD}^{*}$
}

Received on 07 September 2018; Revised on 28 October 2018; Accepted on 2 December 2018

\begin{abstract}
The paper examines the impact of micro-finance on business creation in Nepal through paired sample t-test, chisquare test and Wilcoxon signed rank test. The research is based on primary data collected through structured questionnaires. The survey includes 500 micro-finance clients from four districts of western development region who have been involved in micro-finance programme for last five years. There is a positive association between loan size and its application. The clients who have taken small size of loans, they have mostly spent their loans on domestic purposes and found poor application of loans in micro-business whereas big loan size clients have greater application of loans in productive sectors. The study concludes that micro-business and enterprises creation of people have been significantly improved after involvement in micro-finance programme. Micro finance institutions should give equal priority for non-financial services such as financial literacy and provision of entrepreneurship skills through government and non-government organizations that ultimately helps to utilize micro-credit into productive sectors.
\end{abstract}

Keywords: Employment generation, micro-business, micro-credit, and micro-finance.

\section{INTRODUCTION}

Micro-finance (MF) programme has become a globally popular anti-poverty intervention strategy, based on group lending system and a near-exclusive focus on women. MF has become a significant part of development finance to address financial inclusion and poverty reduction in developing countries like Nepal. These programmes have expanded world wide and have huge memberships in South and Southeast Asia, Africa and Latin America. The basic aim of MF is to break the cycle of indebtedness that plague the rural developing countries, where people are largely depending on the informal lending system and always suffering from the chronic shortage of capital required for financing their livelihoods. Micro-finance institutions (MFIs) deliver financial products to the economically active poor, a market segment underserved by mainstream financial institutions. In fact, MF is a way of reaching to the poor and marginalized people that facilitates to develop an inclusive financial environment in the nation.

Ledgerwood (1999) has highlighted the following reasons that helped in the growth of micro-finance industry: (i) the promise of reaching the poor, (ii) the promise of financial sustainability, (iii) the potential to build on traditional systems, (iv) the contribution of micro-finance to strengthening and expanding existing formal financial systems, (v) the growing number of success stories and (vi) the availability of

\footnotetext{
* Dr. Dhungana is Lecturer in School of Business, Pokhara University, Nepal.

E-mail:dhunganabharat.pu@gmail.com
} 
better financial products as a result of experimentation and innovation.

Around the world, micro and small enterprises are an essential driver of job creation, innovation and socio-economic transformation to the people who are socially, financially and geographically marginalized. These enterprises generate income and create employment opportunities that facilitate for sustainable development because they are firmly rooted in their communities. However, in developing and emerging countries, limited access to financing is often a barrier to the creation, growth, and sustainability of these enterprises. So, MF is a tool of financial inclusion and way of empowering people through collateral free micro-credit to initiate micro-business or enterprises.

MF is unique among development intervention that helps to transform the socio-economic status of the people through micro-credit services, especially for poor and disadvantaged people. The formal financial institutions like commercial banks became failure to provide loans to the marginalized people without collateral. The MFIs provide micro-loans to the low-segment people and create an opportunity to become self-sufficient through micro-saving and credit activities. Micro-finance services around the world are popular to the people who have no capacity for collateral against the loans but have indigenous skills and a strong desire to carry out economic activities for self-employment and income generation.

Micro-finance has achieved astonishing accomplishments over the past 30 years. It has demonstrated that poor people are viable customers, created a number of strong institutions focusing on poor people's finance, and begun to attract the interest of private investors. But despite these achievements, there is still a long way to go to extend access to all who need financial services (CGAP, 2006). Specifically, three major challenges define the frontier of financial services for the poor: (i) scaling up quality financial services to serve large numbers of people, (ii) reaching increasingly poorer and more remote people and (iii) lowering costs to both clients and financial service providers. Clients need different kinds of services to solve a wide range of financial problems at different points in time. Figure 2.1 depicts the typical financial needs that can be fulfilled through micro-finance services for the people who have no capacity to take loans from formal financial institutions.

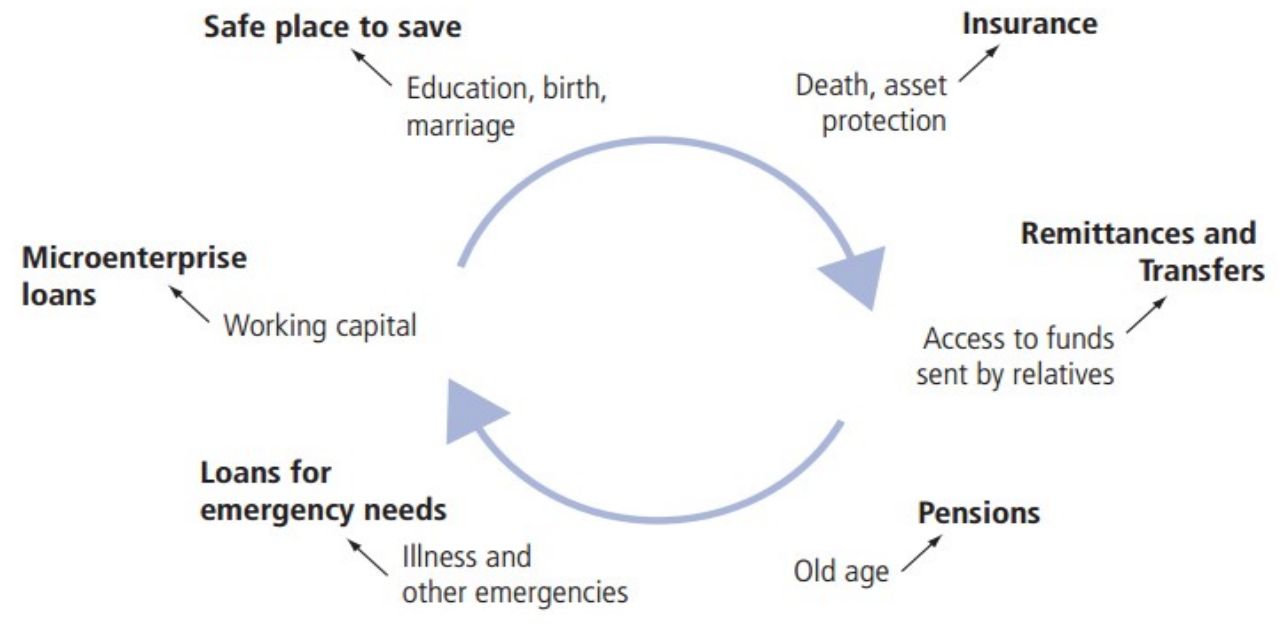

Figure 1. Clients need a variety of services. Adapted from CGAP, Access for All: Building Inclusive Financial Systems, p. 23. 
Micro-enterprises have become increasingly popular in the new development agenda across the globe and more so in the developing world to address income and employment opportunities. Microfinance services encourage people to initiate micro-business or enterprises through the collateral free micro-credit. It helps to improve the living standard of the poor people by generating employment or self-employment opportunities and finally, the socio-economic status of the people will be enhanced.

Micro-loans are encouraging the establishment of micro-enterprises or small businesses. There is no reason to engage in economic activities that do not bring immediate profit because the loan repayment starts soon after being disbursed. They should pay their loan periodically in each group meeting either it may be a weekly or bi-monthly or monthly basis. Borrowers and their family members may have adequate skills or know-how of the activities to improve productivity in their usual occupation or setting of new business. These small business or micro-enterprises generally initiated by the borrowers in the form of sole owner that helps to create self-employment or may generate employment opportunities.

Micro-finance has emerged as a popular mode of finance for the poor and small-scale producers in many countries. The goal of MFIs is to serve the financial needs of un-served or under-served markets as a means of meeting development objectives. These development objectives generally include (i) reducing poverty, (ii) to empower women and other disadvantaged population groups, (iii) to create employment opportunities and (iv) to encourage for micro-business or enterprises creation. MFIs deliver varieties of financial and non-financial services to the clients that help to enhance the socio-economic status of the people. Nowadays, micro-credit has become a popular poverty reduction intervention across the world (The Micro-credit Summit Campaign, 2009).

Past studies indicate that the micro-finance industry has been effective in reaching millions of poor people, in providing them with financial services and in reducing their poverty (Simanowitz \& Walter, 2002). MF programmes help poor borrowers over time and meet their immediate needs (Khandker, 2001). There are many evidences of positive impact of MF, particularly through increasing income (Wright, 2000; McGuire \& Conroy, 2000; Khandker, 2001; Chan \& Ghani, 2011), increasing consumption of household (McGuire \& Conroy, 2000; Rahaman, 2010; Berhane\&Gardebroek, 2011) and reducing vulnerability (Wright, 2000; Zaman, 2000; Salia \& Mbwambo, 2014).

Dhungana (2016) examined loan size and its productive application of loan by clients after involvement in the micro-finance programme in the western development region of Nepal. The study found that clients who have taken small size of loans, they have mostly spent their loans on domestic purposes and found a very poor application of loans in micro-business whereas big loan size clients have a greater application of loans in productive sectors. There is positive association between the size of savings and loans, size of savings and loan application, current loan size and ethnicity, loan size and duration of membership, and finally loan size and its application. The research finds MF intervention facilitates to generate self-employment and employment opportunities through micro-credit services.

Zhiri (2017) examined the impact of micro-finance services on performance of small and medium scale enterprises in Zaria Metropolis. The research design used was cross- sectional and descriptive. The study revealed that the micro-finance services have a significant impact on the level of entrepreneurship activities of SMEs in Zaria Metropolis. The study recommends that the amount of loan given by MFIs to SMEs should be increased and they should also be encouraged to save to enable them grow and propel their enterprises.

The concept of micro-finance existed in its traditional form in Nepal as 'dhikuti' and 'guthiyar'. The history of the cooperative dates back to 1956 when 13 cooperatives were established by the government 
in Chitwan district. The establishment of the cooperatives has been considered as the beginning foundation for micro-credit programme in Nepal. The growth and development of Nepalese microfinance institutions have been presented in Table 1 .

Table 1

Growth and Development of Nepalese Micro-finance Institutions

\begin{tabular}{lcccccccccc}
\hline \multirow{2}{*}{$\begin{array}{l}\text { Micro-finance } \\
\text { institutions }\end{array}$} & 1990 & 1995 & 2000 & 2005 & 2010 & 2012 & 2014 & 2015 & 2016 & $2018^{*}$ \\
\cline { 2 - 11 } & 0 & 4 & 7 & 11 & 18 & 24 & 37 & 39 & 41 & 65 \\
MFDBs & 0 & 6 & 19 & 20 & 15 & 16 & 15 & 15 & 15 & 14 \\
SCCs & 0 & 0 & 7 & 47 & 45 & 36 & 29 & 27 & 27 & 24 \\
FINGOs & 0 & 10 & 33 & 78 & 78 & 76 & 81 & 81 & 83 & 103 \\
\hline Total & & & & & &
\end{tabular}

Source: Banking and Financial Statistics, NRB, Various Issues

Note. *Mid July. MFDBs: Micro-finance Development Banks; SCC: Saving and Credit Cooperatives (Limited banking activities) and FINGOs: Financial Intermediary Non-Government Organisations.

MFIs were formally categorized in mid-1990s and there was tremendous growth of MFIs in each year and it has been extended by 65 throughout the country till mid-July 2018. Among them, one Grameen Bikas Bank (rural development banks) is government MFIs (GMFIs)and remaining are retail lending and wholesale lending MFIs working in the private sectors. Moreover, there are 14 saving and credit cooperatives (limited banking activities) and 24 financial intermediaries non-government organizations (FINGOs) that also provides micro-finance services in Nepal.

The Nepalese MF industry has suffered from diverse nature of problems and challenges that should be addressed in time. The major problems in the area of micro-finance field are lack of financial education, multi-financing problems, ignoring the target people, lack of entrepreneurship skills, poor linkages with government and non-government organizations, high concentration of service providing institutions in urban and sub-urban areas, unhealthy competition, higher interest rate, poor regulation and supervision, inadequate government support and poor financial inclusion.

The status of financial inclusion in Nepal is not satisfactory and three fourth (75.0 percent) of the people have still no bank accounts at the formal financial institutions (World Bank, 2014). Large numbers of people are still depending on the informal lending system in the country especially in hilly and rural areas due to poor financial inclusion. Unless financial inclusion is made effective, the majority of the people will be deprived of formal financial services. In fact, building an inclusive financial system is a challenging task that requires a high degree of efforts and commitment.

The objective of the paper is to examine the impact of micro-finance on business creation of the people living in the western development region of Nepal. 


\section{DATA AND METHODS}

The data has been collected from primary sources through survey questionnaires. The multistage cluster sampling method has been applied due to the wide geographical area to represent the sample from each zone of the western development region of Nepal. Out of the sixteen districts in the region, MF access has been reached into fourteen districts. Four districts have been randomly selected representing each zone of western development region. After selecting the districts, few branches have been randomly selected where 'D class' MFIs have provided MF services since last five or more years. There are number of centers providing MF services to the people in the study area, so few centers have been randomly selected in the process of multi-stage sampling techniques. Finally, the clients, who are involved in MF programme since the last five or more years in 'D class' MFIs, have been randomly selected in clients' survey.

The sample size before adjustment of the design effect is 317 . The sample size has been adjusted to account for intra-cluster correlation. The adjusted $n=n \times$ design effect. Here, the design effect 1.5 has been taken as recommended for social rating (EDA Rural Systems, 2006). Thus, the adjusted sample size after incorporating design effect is 476 . Also by allowing the five percent potential non-response, the final calculated sample size is 500. The survey includes 500 micro-finance clients from four districts of western development region consisting of 300 government micro-finance institutions (GMFIs) and 200 private MFIs (PMFIs) clients who are involved in the micro-finance programme since last five years. The study has been confined to the 'D class micro-finance institutions (MFIs) working in the western development region (WDR) ${ }^{1}$ of Nepal. The parametric test (paired sample t-test) and non-parametric test (Wilcoxon signed rank test and chi square test) have been used to evaluate the impact of MF on microenterprises creation and employment generation.

\section{RESULTS AND DISCUSSIONS}

\subsection{Economic Characteristics of Respondents}

The major economic characteristic of respondents such as earning and dependent members, land and house status, banking access clients and loan taking clients have been presented:

\section{Earning and Dependent Family Members}

Earning and dependent members of clients' family have been assessed with the help of earning members to total family member ratio and dependent members to total family member ratio. The earning and dependent members in terms of ethnicity have been presented in Table 2.

The ratio of dependent members (50.8 percent) is relatively higher than earning members (49.2 percent) in a family. It refers that size of the dependent person in a family is greater than earning members. Majority of Janajati (55.3 percent) has higher earnings ratio and Adhibasi has lower (42.2 percent). Dalit has equal (50.0 percent) proportion of earning and dependent members in a family. The study shows that the participation of male members (27.1 percent) is relatively higher in earnings than female (22.1 percent) members.

\footnotetext{
${ }^{1}$ WDR is one of the five development regions of Nepal includes three administrative zones and 16 districts. It is the second largest development region in terms of geographical area and the third in terms of population (CBS, 2012).
} 
Table 2

Earning and Dependent Members

\begin{tabular}{lllll}
\hline Ratio & Ethnicity & Male & Female & Total \\
\hline Earning members to total family member & Dalit $^{2}$ & 29.6 & 20.4 & 50.0 \\
(percent) & Janajati $^{3}$ & 29.8 & 25.5 & 55.3 \\
& Adhibasi $^{4}$ & 23.8 & 18.4 & 42.2 \\
& BCO $^{5}$ & 25.1 & 24.0 & 49.1 \\
\hline Total & & 27.1 & 22.1 & 49.2 \\
\hline Dependent members to total family member & Dalit & 23.2 & 26.8 & 50.0 \\
(percent) & Janajati & 21.9 & 22.8 & 44.7 \\
& Adhibasi & 28.9 & 28.9 & 57.8 \\
& BCO & 26.6 & 24.3 & 50.9 \\
\hline Total & & 25.1 & 25.7 & 50.8 \\
\hline${ }^{2}$ Denotes to lower caste & & & Source: Field survey, 2014 \\
${ }^{3}$ Refers to the ethnic groups & & & & \\
${ }^{4}$ Denotes to indigenous groups & & & &
\end{tabular}

\section{Banking Access Clients}

Banking access clients refer to those MF clients who have also received formal banking services from commercial and development banks. The banking access clients in terms of ethnicity have been presented in Table 3.

Table 3

\section{Banking Access Clients}

\begin{tabular}{|c|c|c|c|c|c|}
\hline \multirow{2}{*}{ Bank account } & \multicolumn{5}{|c|}{ Ethnic group } \\
\hline & Dalit & Janajati & Adhibasi & $\mathrm{BCO}$ & Total \\
\hline Yes & $\begin{array}{r}15 \\
(11.0)\end{array}$ & $\begin{array}{r}57 \\
(32.0)\end{array}$ & $\begin{array}{r}18 \\
(48.6)\end{array}$ & $\begin{array}{r}64 \\
(43.2)\end{array}$ & $\begin{array}{r}154 \\
(30.8)\end{array}$ \\
\hline No & $\begin{array}{r}122 \\
(89.0) \\
\end{array}$ & $\begin{array}{r}121 \\
(68.0) \\
\end{array}$ & $\begin{array}{r}19 \\
(51.4)\end{array}$ & $\begin{array}{r}84 \\
(56.8) \\
\end{array}$ & $\begin{array}{r}346 \\
(69.2) \\
\end{array}$ \\
\hline Total & 137 & 178 & 37 & 148 & 500 \\
\hline
\end{tabular}

Note. Figures in parentheses represent the row percentage value.

Majority of the clients are largely depending on MF services because they have no access (69.2 percent) with formal banking institutions. Only 30.8 percent of the clients have banking access and taking additional services to fulfill their financial requirement. Out of banking access clients, 21.6 percent have an account in a single bank, 8.6 percent have in two banking institutions and 0.6 percent has more than two banking institutions. 


\section{Loan Taking Clients}

The clients who have taken loans before and after membership have been assessed and presented through Table 4.

Table 4

Loan Taking Clients

\begin{tabular}{lccccc}
\hline \multirow{2}{*}{ Status } & \multicolumn{2}{c}{ Before membership } & & \multicolumn{2}{c}{ After membership } \\
\cline { 2 - 3 } \cline { 5 - 6 } & Frequency & Percent & & Frequency & Percent \\
\hline Yes & 110 & 22.0 & & 498 & 99.6 \\
No & 390 & 78.0 & & 2 & 0.4 \\
\hline Total & 500 & 100.0 & & 500 & 100.0 \\
\hline
\end{tabular}

Source: Field survey, 2014

Table 4 shows that a large number of clients (78.0 percent) had no access of loan before membership. Since MF provides micro-credit without collateral security, so loan taking clients are now 99.6 percent. Though loan taking clients has been significantly increased in Nepalese MF industry, there is a lack of adequate attention for productive investment. MFIs should be more responsible regarding the productive application of loans that may help to enhance the socio-economic status of clients.

\subsection{Micro-Finance Intervention Impact}

MFIs around the world deliver small size loans and savings facilities to the people who are excluded by formal financial institutions like commercial banks (Mathie, 2001). Many studies show that MF has played a positive impact on various dimensions that have been presented in the form of both descriptive and inferential statistics.

\section{Micro-Business and Enterprises Creation}

MFI supports clients for micro-business and enterprises creation through the supply of collateral free micro-credit. The status of micro-business and enterprises creation before and after involvement in $\mathrm{MF}$ programme has been presented in Table 5.

Table 5

Micro-Business and Enterprises Creation

\begin{tabular}{lccccc}
\hline \multirow{2}{*}{ Status } & \multicolumn{3}{c}{ Before } & & \multicolumn{2}{c}{ After } \\
\cline { 2 - 3 } \cline { 5 - 6 } & Frequency & Percent & & Frequency & Percent \\
\hline Yes & 218 & 43.6 & & 315 & 63.0 \\
No & 282 & 56.4 & & 185 & 37.0 \\
\hline Total & 500 & 100.0 & & 500 & 100.0 \\
\hline
\end{tabular}

Source: Field survey, 2014 and authors' calculation.

Table 5 shows that 43.6 percent of the clients had only micro-business and enterprises before involvement in MF programme. Micro-business and enterprises creation rate have been considerably increased after intervention however, 37.0 percent clients still do not have micro-business and enterprises. Since there is lacking of enough orientation regarding the productive application of loans, so MFIs should pay adequate attention and encourage clients to establish enterprises through the provision of 
entrepreneurship skills in addition to micro-credit services. The status of micro-business and enterprises creation has been presented in Table 6.

Table 6

Status of Micro-Business and Enterprises Creation

\begin{tabular}{llrrrr}
\hline Impact on & Ranks & $\mathrm{N}$ & Percent & $\mathrm{Z}$ & $\mathrm{p}$-value \\
\hline \multirow{3}{*}{ Micro-business creation } & Negative & 11 & 2.2 & & \\
& Positive & 108 & 21.6 & -8.89 & $0.000^{*}$ \\
& Ties & 381 & 76.2 & & \\
\hline
\end{tabular}

Source: Field survey, 2014 and author's calculation Note. Negative ranks denote after membership before membership and positive ranks denotes after membership before membership.

*Significant at 5 percent level.

The study shows that 21.6 percent of the clients have a positive impact on micro-business creation after involvement in MF programme. However, 76.2 percent clients have no effect on micro-business creation due to already initiated before involvement in MF programme and some of them have still no micro-business and enterprises. Since the p-value of Wilcoxon signed rank test is less than five percent level of significance, so the alternative hypothesis has been accepted. The inferential statistics show that MF intervention generates micro-business and enterprises through micro-credit services.

\section{Nature of Micro-Business and Enterprises}

The nature of micro-business and enterprises has been broadly categorized into three groups i.e. manufacturing and production, trading and service business. Manufacturing and production enterprises represent small scale manufacturing including agricultural and livestock production. Trading enterprises include buying and selling of goods such as grocery products, clothes, stationary and so on. Finally, service business refers to hotel, restaurant, tailoring, repairing and so on. The nature of micro-business and enterprises has been presented in Table 7.

Table 7

Nature of Micro-Business and Enterprises

\begin{tabular}{lccccc}
\hline \multirow{2}{*}{ Nature of business } & \multicolumn{2}{c}{ Before } & & \multicolumn{2}{c}{ After } \\
\cline { 2 - 3 } \cline { 5 - 6 } \cline { 5 - 6 } & Frequency & Percent & & Frequency & Percent \\
\hline Manufacturing and production & 16 & 7.3 & & 41 & 13.0 \\
Trading related & 89 & 40.8 & & 135 & 42.9 \\
Service related & 113 & 51.8 & & 139 & 44.1 \\
\hline Total & 218 & 100.0 & & 315 & 100.0 \\
\hline
\end{tabular}

Source: Field survey, 2014 and authors' calculation

Majority of clients ( 51.8 percent) had service related business before involvement in MF programme and this sector has still occupied a higher proportion (44.1 percent). Though number of enterprises related to manufacturing and production is relatively low in pre ( 7.3 percent) and post (13.0 percent) intervention, the growth rate of this sector is relatively higher as compared to trading and service 
sectors. The manufacturing and production (including agriculture and livestock) related enterprises play a significant role in national economy, therefore, MFIs should encourage this sector through a special provision that can contribute not only in the welfare of clients but also for community and nation.

\section{Status of Micro-Business and Employment}

The status of micro-business and employment explores a number of micro-business creation, number of employees per business, total employment and employment generation in terms of ethnicity. The status of micro-business and employment has been presented in Table 8.

Table 8

\section{Status of Micro-Business and Employment}

\begin{tabular}{ccccccc}
\hline \multirow{2}{*}{$\begin{array}{c}\text { No of } \\
\text { micro-business }\end{array}$} & $\begin{array}{c}\text { No. of employees } \\
\text { per business }\end{array}$ & Total employment & \multicolumn{3}{c}{ Employment and ethnicity } \\
\cline { 4 - 6 } & 1 & 111 & Dalit & Janajati & Adhibasi & BCO* \\
\hline 111 & 2 & 272 & 22 & 34 & 13 & 42 \\
136 & 3 & 99 & 47 & 113 & 24 & 88 \\
33 & 4 & 92 & 28 & 21 & 15 & 35 \\
23 & 5 & 25 & 18 & 50 & 8 & 16 \\
5 & 6 & 12 & 15 & 10 & 0 & 0 \\
2 & 7 & 7 & 0 & 5 & 0 & 8 \\
1 & 8 & 24 & 4 & 11 & 2 & 0 \\
3 & 12 & 12 & 2 & 10 & 8 & 1 \\
1 & Total & 654 & 138 & 256 & 70 & 0 \\
\hline 315 & & \multicolumn{5}{c}{ Source Field survey, 2014 and author's calculation }
\end{tabular}

Note: Average employment per business $=654 / 315=2.1$.

The study shows that 315 micro-business and enterprises have been created by clients that represent 63.0 percent of the clients' involvement in enterprise creation. The average employment rate per business is 2.1, out of which Janajati (0.81) has a higher employment rate per business and Adhibasi (0.22) has lower. Most of the micro-business (78.42 percent) has provided employment opportunities for up to two people per micro-business. It may be concluded that MF facilitates to generate self-employment and employment opportunities through micro-credit services.

\section{Size of Loans and Its Application}

The loan size and its application have been compared to find out the proper utilization of loans by the clients. The size of loans and its application have been presented in Table 9. As per the monetary policy 2015/16, the maximum loan size is Rs. 300,000 for collateral- free loans and Rs. 700,000 for collateral based loans. Most of the clients (87.4 percent) have taken loans between Rs. 25,000 to Rs. 100,000, out of which 37.2 percent have loan size of Rs. 25,001 to Rs. 50,000, 26.8 percent have Rs. 50,001 to Rs. 75,000, and 23.4 percent have Rs. 75,001 to Rs. 100,000.

It is obvious from Table 9 that those clients whose size of loans are less than Rs. 25,000, there is poor application (69.8 percent) of loans in the productive sector. The loan size between Rs. 25,001 to Rs. 50,000 has only 50.0 percent application of loans in the productive sector. But loan size having 
Table 9

Size of Loans and Its Application

\begin{tabular}{lrrr}
\hline \multirow{2}{*}{ Size of current loan (Rs.) } & \multicolumn{2}{c}{ Application of loans } & \multirow{2}{*}{ Total } \\
\cline { 2 - 3 } No loan & Productive & Unproductive & 16 \\
& 6 & 10 & $(100.0)$ \\
Below 25,000 & $(37.5)$ & $(62.5)$ & 43 \\
& 13 & 30 & $(100.0)$ \\
$25,001-50,000$ & $(30.2)$ & $(69.8)$ & 186 \\
$50,001-75,000$ & 94 & 92 & $(100.0)$ \\
& $(50.5)$ & $(49.5)$ & 134 \\
$75001-100,000$ & 100 & 34 & $(100.0)$ \\
& $(74.6)$ & $(25.4)$ & 117 \\
Above 100,000 & 98 & 19 & $(100.0)$ \\
& $(83.8)$ & $(16.2)$ & 4 \\
Total & 4 & $(0.0)$ & $(100.0)$ \\
\hline
\end{tabular}

Source: Field survey, 2014 Note. $\chi^{2}=68.417$ at 5 degree of freedom and $p$-value $=0.000$. Figures in parentheses represent percentage value.

greater than Rs. 50,000 has the higher degree of the loan application in the productive sector. The clients having loan size of Rs. 50,001 to Rs. 75,000 has 74.6 percent application of loan in the productive sector. Similarly, loan size between Rs. 75,001 to Rs. 100,000 has 83.8 percent application, and loan size having more than Rs. 100,000 has cent percent application in the productive sector.

The study shows that who have taken loans below Rs. 25,000, mostly spent on household and domestic use and found poor initiation of micro-business. Since p-value of $\chi^{\wedge} 2$ test is less than five percent significance level, so there is a positive association between loan size and its application. It refers that higher the loan size, higher the application of loans in the productive sector and vice-versa. So, MFIs should provide the optimum size of loans to the clients as per the provision of monitory policy to increase its productive application however, strict monitoring and supervision is essential.

\section{Impact of Micro-Finance on Income Level}

The paired sample t-test has been used to examine the impact of MF intervention on the income level of clients. The impact of micro-finance on the income level of the clients has been presented in Table 10.

Since the $t$ value of micro-business and enterprises income of clients is 26.5 and its corresponding p-value is less than five percent level of significance, so the alternative hypothesis has been accepted. Similarly, the $t$ value of total income of clients is 38.5 and its corresponding $p$-value is less than five percent level of significance, so the alternative hypothesis has been accepted. Thus, MF intervention has increased the income level of the clients significantly. 
Table 10

Impact of Micro-Finance on Income Level

\begin{tabular}{|c|c|c|c|c|c|c|c|c|}
\hline \multirow{3}{*}{ Income } & \multicolumn{8}{|c|}{ Paired differences } \\
\hline & \multirow{2}{*}{ Mean } & \multirow{2}{*}{$\begin{array}{l}\text { Std. } \\
\text { dev. }\end{array}$} & \multirow{2}{*}{$\begin{array}{c}\mathrm{SE} \\
\text { mean }\end{array}$} & \multicolumn{2}{|c|}{$95 \%$ confidence interval } & \multirow{2}{*}{$\mathrm{t}$} & \multirow{2}{*}{$\mathrm{df}$} & \multirow{2}{*}{ p-value } \\
\hline & & & & Lower & Upper & & & \\
\hline $\begin{array}{l}\text { Micro-business and } \\
\text { enterprises }\end{array}$ & 0.40 & 0.24 & 0.02 & 0.37 & 0.43 & 26.47 & 243 & $0.000 *$ \\
\hline Total income & 0.38 & 0.22 & 0.01 & 0.36 & 0.39 & 38.55 & 499 & $0.000 *$ \\
\hline
\end{tabular}

*Significant at 5 percent level.

\section{CONCLUSION AND SUGGESTIONS}

The study shows that there is a positive impact on micro-enterprises creation and income levelof the people after MF intervention. One of the significant impacts of MF is to increase the income level of clients after the application of micro-loans into productive sectors. MF intervention has facilitated to generate self-employment and employment opportunities through micro-credit services. It has been found that 21.6 percent of the clients have a positive impact on micro-business creation after involvement in MF programme. The study finds positive association between loan size and its application. The clients who have taken small size of loans, they have mostly spent their loans on domestic purposes and found a very poor application of loans in micro-business whereas big loan size clients have a greater application of loans in productive sectors. MFIs should provide both financial and non-financial services to the clients (such as financial literacy and provision of entrepreneurship skills)that ultimately helps to utilize micro-credit into productive sectors.

\section{REFERENCES}

Berhane, G., \& Gardebroek, C. (2011). Does micro-finance reduce rural poverty? Evidence based on household panel data from Northern Ethiopia. American Journal of Agriculture Economics, 93(1), 43-55.

Central Bureau of Statistics. (2012). National population and housing census, 2011. Kathmandu: Central Bureau of Statistics.

CGAP (2006). Access for all: Building inclusive financial systems. Washington DC: The World Bank.

Chan, S. H., \& Ghani, M. A. (2011). The impact of micro-loans in vulnerable remote areas: Evidence from Malaysia. Asia Pacific Business Review, 17(1), 45-66.

Dhungana, B. R. (2016). Does loan size matter for productive application? Evidence from Nepalese micro-finance institutions. The Journal of Business and Hospitality, 1(1), Nepal Tourism and Hotel Management College, Pokhara, Nepal.

EDA Rural Systems. (2006). Technical note one: Estimating sample size. Gurgaon: EDA Rural System.

Khandker, S. (2001). Does micro-finance really benefit the poor? Evidence from Bangladesh. Paper delivered at Asia and Pacific forum on poverty: Reforming policies and institutions for poverty reduction, Asian Development Bank, Manila, 5-9 February. Retrieved from: http://www.adb.org/poverty/forum/pdf/ khandker.pdf

Ledgerwood, J. (1999). Micro-finance handbook: An institutional and financial perspective. Washington, DC: The 
World Bank.

Mathie, A. (2001). Including the excluded: Lessons learned from the poverty targeting strategies used by microfinance providers. Retrieved from: http://www.coady.stfx.ca/resources/ publications/publications occasional_including.html

McGuire, P. B., \& Conroy, J. D.(2000). The micro-finance phenomenon. Asia-Pacific Review, 7(1), 90-108.

Nepal Rastra Bank. (2017). Banking and financial statistics. Kathmandu: Nepal Rastra Bank.

Rahaman, S. (2010). Consumption difference between micro-credit borrowers and non-borrowers: A Bangladesh experience. The Journal of Developing Areas, 43(2), 313-326.

Salia, P. J., \& Mbwambo, J. S. (2014). Does micro-credit make any difference on borrowers' businesses? Evidences from a survey of women owned micro-enterprises in Tanzania. International Journal of Social Sciences and Entrepreneurship, 1 (9), 431-444.

Simanowitz, A., \& Walter, A. (2002). Ensuring impact: Reaching the poorest while building financially selfsufficient institutions, and showing improvement in the lives of the poorest women and their families. Retrieved from http://www.micro-financegateway.org/content/article/detail/3564

The Micro-credit Summit Campaign (2009). What is micro-credit? The Micro-credit Summit Campaign. Retrieved from http://www.microcreditsummit.org/about/whatis_microcredit

The World Bank. (2014). Global financial development report. The World Bank.

Wright, G. A. N. (2000). Micro-finance systems: Designing quality financial services for the poor. London: Zed Books.

Yunus, M. (2011). Vision 2050: A poverty-free world social business: A step toward creating a new global economic order. The Journal of Social Business, Social Business and New Economics Paradigm, 1(1),7-23.

Zaman, H. (2000). Assessing the poverty and vulnerability impact of micro-credit in Bangladesh: A case study of BRAC. TheWorld Bank. Retrieved from: www.worldbank.org/html /dec/publications/workpapers/ wps2000series/wps2145.pdf

Zhiri, D. D. (2017). Impact of micro-finance services on performance of small and medium scale enterprises (SMEs) In Zaria metropolis. International Journal of Scientific Research in Social Sciences \& Management Studies, 2(1). 